\title{
PEMANFAATAN LIMBAH KECAP KEDELAI DALAM PEMBUATAN NATA DE SOYA
}

\author{
Srikandi ${ }^{*}$ Lilis Sugiarti dan Sugi Hardanto \\ *Jurusan Biologi FMIPA Universitas Nusa Bangsa \\ Jl. K.H. Sholeh Iskandar, Cimanggu, Tanah Sareal- Bogor 16166 \\ *e-mail: sriuus@yahoo.co.id
}

\begin{abstract}
Utilization of Waste of Soy Souce Production for Nata de Soya Product
\end{abstract}

\begin{abstract}
The general objective of the study was to minimize waste of soy sauce production to become food product of nata de soya. Bacteria of Acetobacter xylinum were used for the purpose. Specific objective of the study was to determine the composition of materials in producing nata de soya. Three treatments were used in the study namely: 1) six concentration of the waste $(0 \%, 2.5 \%, 5.0 \%, 7.5 \%, 10 \%, 12,5 \%)$, 2) five concentration of sugar $(0 \%, 3 \%, 6 \%, 9 \%, 12 \%)$, and 3$)$ two concentration of $\left(\mathrm{NH}_{4}\right)_{2} \mathrm{PO}_{4}(0 \%, 0,5 \%)$. Each treatment was replicated in three times. Parameters to be measured was the thick and degree of white colour of the nata de soya produced. The completely factorial randomized design was used in the statistical analysis. The results showed that the best composition: the waste 10\%, sugar $6 \%$ and $\left(\mathrm{NH}_{4}\right)_{2} \mathrm{PO}_{4} \quad 0,5 \%$ for the thickness $2,23 \mathrm{~cm}$ and white colour degree of $37,87 \%$. All treatments and the interactions were significantly different for the thickness $(P=95 \%)$. Treatments of waste and sugar were significantly different for degree of white colour, except for $\left(\mathrm{NH}_{4}\right)_{2} \mathrm{PO}_{4}$ treatments were not significantly different $(\mathrm{P}=95 \%)$.
\end{abstract}

Key words : Waste of soy souce, Acetobacter xylinum, Nata de soya, thickness, degree of white

\begin{abstract}
ABSTRAK
Tujuan umum penelitian adalah untuk memanfaatkan limbah kecap kedelai menjadi produk makanan nata de soya menggunakan Acetobacter xylinum. Tujuan khusus penelitian ini adalah menentukan komposisi media yang paling tepat untuk pembuatan nata de soya dari limbah kecap kedelai. Pembuatan nata de soya dalam penelitian ini menggunakan Rancangan Acak Lengkap (RAL) factorial dengan 3 perlakuan, yaitu 1) enam konsentrasi limbah kecap $(0 \%, 2,5 \%, 5,0 \%, 7,5 \%, 10 \%, 12,5 \%), 2)$ lima konsentrasi gula $(0 \%, 3 \%, 6 \%, 9 \%, 12 \%)$, dan 3$)$ dua konsentrasi $\left(\mathrm{NH}_{4}\right)_{2} \mathrm{PO}_{4}(0 \%$ dan $0,5 \%)$, masing-masing unit perlakuan mendapatkan perlakuan yang sama, diulang sebanyak 3 kali dan dilaksanakan secara serentak. Parameter yang diamati dari setiap unit percobaan adalah ketebalan dan derajat putih nata. Desain penelitian menggunakan rancangan acak lengkap (RAL) factorial untuk analisis statistik. Hasil penelitian menunjukan bahwa komposisi yang paling baik adalah media dengan limbah kecap $10 \%$, gula $6 \%$ dan $\left(\mathrm{NH}_{4}\right)_{2} \mathrm{PO}_{4}$ $0,5 \%$ dengan ketebalan $2,23 \mathrm{~cm}$ dan derajat putih $37,87 \%$. Perlakuan konsentrasi limbah kecap, gula dan $\left(\mathrm{NH}_{4}\right)_{2} \mathrm{PO}_{4}$ dan interaksinya berpengaruh nyata terhadap ketabalan nata yang dihasilkan (P=95\%). Perlakuan konsentrasi limbah kecap dan gula, mempengaruhi secara nyata derajat putih nata sedangkan untuk perlakuan $\left(\mathrm{NH}_{4}\right)_{2} \mathrm{PO}_{4}$ tidak mempengaruhi secara nyata $(\mathrm{P}=95 \%)$
\end{abstract}

Kata kunci : Limbah Kecap, Acetobacter xylinum, Nata de soya, Ketebalan, Derajat Putih.

\section{PENDAHULUAN}

Kecap dibuat dengan cara fermentasi yaitu fermentasi kapang dan fermentasi khamir serta berbagai jenis bakteri (Rahayu, 1985). Setelah tahap fermentasi selesai dilakukan penyaringan dan pengepresan, sehingga akan diperoleh filtrat dan ampas.

Filtrat selanjutnya dijadikan kecap sedangkan ampas dapat digunakan untuk pakan ternak atau dibuang sebagai lirnbah. Limbah kecap termasuk ke dalam golongan limbah organik dimana bila tidak diolah akan menimbulkan pencemaran.

Pemanfaatan limbah kecap pada industri skala besar hanya sebatas untuk pakan ternak tetapi jika jumlah limbah terlalu besar sebagian limbah dibakar, sehingga dapat menimbulkan pencemaran 
udara.

Pada industri skala kecil umumnya limbah kecap yang dihasilkan dibuang langsung ke sungai, hal ini mengakibatkan kondisi lingkungan perairan menjadi tidak menguntungkan bagi kehidupan biota. Karena oksigen terlatur akan menurun dan kebutuhan oksigen kimia akan meningkat. Keadaan ini menyebabkan kematian pada ikanikan yang ada dalam perairan tersebut.

Sampai dengan saat ini masih sangat sedikit penelitian tentang pemanfaatan limbah kecap yang diperkirakan masih memiliki kandungan karbohidrat, protein dan lainya meski dalam jumlali yang sedikit. Pemanfaatan kandungan tersebut belum banyak di lihat oleh para peneliti untuk menghasilkan suatu produk yang lebih bermanfaat.

\section{BAHAN DAN METODE}

\section{A. Bahan dan Alat}

1. Bahan

Bakteri Acetobacter xylinum, limbah kecap kedelai, aquades, gula pasir, asam asetat 25\%, $\left(\mathrm{NH}_{4}\right)_{2} \mathrm{PO}_{4}, \mathrm{~K}_{2} \mathrm{HPO}_{4}, \mathrm{MgSO}_{4}$, dan air kelapa.

\section{Alat}

Botol selai, gelas ukur, pipet, tabung reaksi, timbangan, laminar air flow, blender, spatula, saringan, autoclave, oven, incubator, $\mathrm{pH}$ meter, ose.

\section{B. Metode}

Penelitian ini menggunakan metode eksperimental terdiri dari 3 perlakuan, yaitu limbah kecap terdiri dari 6 konsentrasi $(0 \%$, $2,5 \%, 5,0 \%, 7,5 \%, 10 \%, 12,5 \%)$, gula 5 konsentrasi $(0 \%, 3 \%, 6 \%, 9 \%, 12 \%)$ dan $\left(\mathrm{NH}_{4}\right)_{2} \mathrm{PO}_{4}$ terdiri dari 2 konsentrasi $(0 \%$, $0,5 \%)$, masing-masing unit perlakuan dapat dilihat pada Tabel. 1 .

Parameter setiap percobaan adalah ketebalan dan derajat putih nata. Setiap parameter pengamatan kemudian diolah dengan menggunakan metode RALF dan diproses secara univariat, yang akan menentukan formulasi paling baik terhadap kualitas nata yang dihasilkan serta faktor yang paling berpengaruh terhadap kualitas nata.

Pembuatan nata dari limbah kecap terdiri dari beberapa tahap yaitu :

\section{Pembuatan starter}

Air kelapa disaring dengan beberapa lapis kain kasa. Kemudian dipanaskan sampai mendidih lalu tambahkan gula, asam asetat 25\% (10-20 $\mathrm{mL}$ untuk setiap satu liter air kelapa), larutan diaduk hingga larut. Larutan ini dinamakan larutan air kelapa asam bergula.

Tiga gram $\left(\mathrm{NH}_{4}\right)_{2} \mathrm{PO}_{4}$ dilarutkan ke dalam $200 \mathrm{~mL}$ air kelapa, larutan ini didihkan dan dituang ke dalam air kelapa asam bergula. Ketika masih panas media dipindahkan ke dalam toples masingmasing $500 \mathrm{~mL}$, toples ditutup dengan kertas koran steril. Setelah dingin media diinokulasi dengan bakteri Acetobacter xylinum dari biakan agar miring sebanyak \pm 5 ose, kemudian dinkubasi pada suhu $30^{\circ} \mathrm{C}$ selama $6-9$ hari.

\section{Pembuatan media fermentasi}

\section{a. Pembuatan larutan stok limbah kecap kedelai $50 \%$}

Limbah kecap yang berupa padatan, ditimbang sebanyak $5 \mathrm{~kg}$, kemudian dilarutkan dengan $5 \mathrm{~L}$ akuades. Campuran tersebut di blender hingga halus dan kemudian disaring menggunakan kain bersih. Larutan hasil penyaringan tersebut dipanaskan hingga mendidih selama 15 menit (larutan A).

\section{b. Larutan stok gula $50 \%$}

Gula putih ditimbang sebanyak 5 $\mathrm{kg}$ dan kemudian dicampur dengan menggunakan akuades sebanyak $5 \mathrm{~L}$. Campuran tersebut dilarutkan dengan menggunakan stirrer hingga larut sempurna dan kemudian disaring dengan menggunakan kain bersih hingga bebas kotoran. Larutan tersebut kemudian dipanaskan hingga mendidih selama 15 
menit (larutan B).

\section{c. Larutan stok $\left(\mathrm{NH}_{4}\right)_{2} \mathrm{PO}_{4}$}

$\left(\mathrm{NH}_{4}\right)_{2} \mathrm{PO}_{4}$ ditimbang sebanyak $100 \mathrm{~g}$ kemudian dicampur dengan $900 \mathrm{ml}$ akuades. Campuran tersebut dilarutkan dengan menggunakan stirrer hingga larut sempuma dan kemudian disaring dengan menggunakan kain bersih hingga bebas kotoran. Larutan tersebut kemudian dipanaskan hingga mendidih selama 15 menit (larutan C).

\section{d. Larutan stok asam asetat $25 \%$}

Asam asetat glasial dipipet sebanyak $25 \mathrm{ml}$ kemudian dicampur dengan menggunakan akuades sebanyak $100 \mathrm{ml}$. Campuran tersebut dilarutkan dengan menggunakan stirrer hingga larut sempurna kemudian disaring dengan menggunakan kain bersih hingga bebas kotoran. Larutan tersebut kemudian dipanaskan hingga mendidih selama 15 menit (larutan D).

\section{Pembuatan kombinasi media fermentasi}

Sebanyak 5 L larutan A ditambah \pm $75 \mathrm{ml}$ larutan D. Penambahan larutan D dilakukan sedikit demi sedikit sehingga $\mathrm{pH}$ larutan mencapai 4,4 - 5 (larutan E). Selanjutnya masing-masing larutan (Larutan $\mathrm{E}, \mathrm{B}$ dan $\mathrm{C}$ ) dipipet dengan volume yang sesuai dengan kombinasi perlakuan dan dimasukan ke dalam botol selai yang telah disterilisasi. Akuades ditambahkan hingga volume masing - masing perlakuan $200 \mathrm{ml}$. Pekerjaan ini dilakukan sebanyak tiga kali ulangan dan dilakukan secara aseptis di laminar air flow.

\section{Proses fermentasi nata dan Pemanenan}

Larutan starter yang sudah berumur 7 hari dipipet sebanyak $10 \mathrm{ml}(5 \%)$ ke setiap botol selai yang sudah diisi oleh $200 \mathrm{ml}$ media fermentasi. Media fermentasi yang sudah ditambahkan starter diaduk dengan rata. Seluruh botol yang berisi media fermentasi ditutup dengan menggunakan kertas koran yang sudah disterilkan dan diikat dengan menggunakan karet. Seluruh botol tersebut dinkubasikan dalam inkubator pada suhu $30^{\circ} \mathrm{C}$ selama 14 hari. Nata yang terbentuk dari setiap unit perlakuan diambil dan selanjutnya direndam dalam air yang setiap hari diganti selama 3 hari, kemudian direbus pada suhu $100{ }^{\circ} \mathrm{C}$ selama 30 menit kemudian dilakukan pengamatan.

\section{Pengamatan}

Produk nata yang didapat dari hasil penelitian kemudian diamati untuk kualitasnya meliputi ketebalan nata dan derajat putih.

\section{a. Ketebalan}

Ketebalan nata diukur dengan menggunakan mistar pada tingkat ketelitian satu mili meter. Nata diukur ketebalannya dari tepi atas sampai tepi bawah.

\section{b. Derajat putih}

Derajat putih diukur dengan menggunakan alat whiteness meter, prinsip pengukuran adalah membandingkan derajat putih pada bahan yang diukur yaitu nata, dengan larutan standar $\mathrm{MgO}$ atau $\mathrm{BaCL}_{2}$ yang memiliki derajat putih $100 \%$. Alat sebelumnya dikondisikan dengan larutan $\mathrm{MgO}$ atau $\mathrm{BaCL}_{2}$ untuk memperoleh derajat putih $100 \%$, kemudian barulah dilakukan pengukuran terhadap contoh nata dari setiap perlakuan. Pada penelitian ini standar yang digunakan adalah standar $\mathrm{BaCL}_{2}$.

\section{c. $\mathbf{p H}$}

pH media fermentasi diukur pada setiap kombinasi perlakuan sebelum dan sesudah inkubasi/fementasi.

\section{d. Uji organoleptik}

Informasi penerimaan produk nata yang dihasilkan seperti tekstur, rasa dan warna dilakukan uji organoleptik. Tekstur nata yang diperoleh dari kombinasi perlakuan terbaik dibandingkan dengan tekstur nata de 
coco yang berada di pasaran.

\section{e. Uji proksimat}

Nata de soya hasil fermentasi dilakukan pengujian dengan parameter kadar air, kadar abu, serat kasar, protein, lemak serta karbohidrat.

\section{HASIL DAN PEMBAHASAN}

Pada dasarnya kualitas nata dapat ditinjau dari beberapa segi yaitu ketebalan, derajat putih, atau juga dari segi kekenyalan. Semakin tebal nata maka semakin baik kualitasnya, hal ini menunjukkan bahwa media untuk pertumbuhan bakteri Acetobacter xylinum sudah sesuai, karena bakteri dapat terus menjalankan kegiatan metabolismenya untuk membentuk selulosa ekstraseluler (nata), yang selama waktu inkubasi akan semakin bertambah ketebalannya. Begitupun derajat putih, semakin putih nata maka semakin baik kualitasnya. Pada penelitian yang dilakukan ini pengamatan kualitas nata dilihat dari dua segi yaitu ketebalan dan derajat putih.

\section{Ketebalan}

Perlakuan tanpa penambahan limbah kecap pada media yang telah diinokulasi dengan bakteri Acetobacter xylinum terlihat keruh, tetapi tidak menunjukan adanya pembentukan selulosa nata setelah waktu inkubasi 14 hari.

Hal ini menunjukan bahwa media harus mengandung berbagai nutrisi seperti, nitrogen, karbon, vitamin, dan mineral. Masing-masing nutrisi tersebut mempunyai fungsi yang berlainan, nitrogen diperlukan dalam pembentukan senyawa - senyawa organik untuk pertumbuhan sel, kebutuhan minimat Nitrogen $0,8 \%$. Karbon digunakan untuk pembentukan beberapa senyawa organik yang diperlukan dalam pembentukan protoplasma. Selain karbon dan Nitrogen juga beberapa mineral yang mendukung pertumbuhan mikroorganisme seperti $\mathrm{Mg}^{2+}, \mathrm{K}^{+}$, dan $\mathrm{Ca}^{2+}$.

Sumber nitrogen yang terdapat dalam media fermentasi pada perlakuan (LO) dapat digunakan oleh bakteri Acetobacter xylinum untuk pertumbuhannya, tetapi masih belum mencukupi untuk dapat menghasilkan metabolit ekstraseluler berupa lapisan membran nata. Pembentukan lapisan membran nata oleh bakteri Acetobacter xylinum membutuhkan nitrogen lebih banyak yang berasal dari penambahan konsentrasi limbah kecap. Komposisi media tanpa penambahan limbah kecap yang mengandung mineral $\mathrm{K}^{+}, \mathrm{Mg}^{+}$dan juga $\mathrm{Ca}^{2+}$ sehingga komposisi media hanya terdiri dari gula sebagai sumber karbon, $\left(\mathrm{NH}_{4}\right)_{2} \mathrm{PO}_{4}$ sebagai sumber nitrogen dan phospat.

Menurut Hasid (1970) dalam Hubies dkk (1996), $\mathrm{K}^{+}$dapat membantu pembentukan prekursor selulosa nata, sedangkan $\mathrm{Mg}^{2+}$ dan $\mathrm{Ca}^{2+}$, diperlukan untuk mengontrol kerja enzim ekstra seluler dan membentuk ikatan polisakarida. Rata rata minimum penggunaan ketiga mineral tersebut adalah $50 \mathrm{mg} / \mathrm{L}$ (Jawetz 1984). Hasil penelitian yang dilakukan menunjukkan babwa limbah kecap kedelai mengandung total nitrogen $2,57 \%$, kalsium $2077 \mathrm{mg} / \mathrm{L}$, phospat $3450 \mathrm{mg} / \mathrm{L}$, dan kalium $2070 \mathrm{mg} / \mathrm{L}$ (Wowor dkk, 2007).

Pada perlakuan tanpa penambahan gula (GO), media fermentasi juga terlihat keruh tanpa pembentukan membran nata. Media fermentasai yang keruh menunjukan adanya pertumbuhan bakteri Acetobacter xylinum. Sumber karbon dari penambahan gula diperlukan untuk pertumbuhan bakteri Acetobacter xylinum untuk membetuk metabolit ekstraseluler berupa nata

Hasil penelitian yang dilakukan oleh Hubeis dkk (1996), diketahui bahwa penambahan gula atau sukrosa akan berpengaruh terhadap hasil nata yang diperoleh. Glukosa merupakan bahan pembentuk nata, semakin banyak glukosa yang ditambahkan pada media maka rendemen nata pun meningkat. Menurut Herman (1979) dalam Hubeis dkk.(1996) bahwa nata terbentuk sampai konsentrasi glukosa $15 \%$, sedangkan pada konsentrasi yang lebih besar rendemennya menurun.

Penambahan jumlah gula yang 
terlalu berlebih ternyata juga tidak dianjurkan karena gula yang berlebih yang ditambahkan pada media, sisanya akan dikonversi menjadi asam asetat, selanjutnya akan diubah menjadi gas $\mathrm{CO}_{2}$ dan $\mathrm{H}_{2} \mathrm{O}$ secara aerobik melalui lintasan asam trikarboksilat. Gas tersebut akan menjadi pemisah antara media dan nata yang terbentuk, sehingga akan menjadi penghambat pertumbuhan bakteri Acetobacter xylinum, akibatnya pembentukan rendemen nata menjadi tipis dan kurang optimum (Carr dan Passmore, 1974 dalam Hubeis dkk. 1996). Hubeis berpendapat pula bahwa dengan banyaknya sukrosa yang diubah menjadi asam, hal ini akan menurunkan $\mathrm{pH}$ media menjadi terlalu rendah.

Pada Gambar 1 dapat dilihat bahwa perlakuan tanpa penambahan $\left(\mathrm{NH}_{4}\right)_{2} \mathrm{PO}_{4} \quad$ (N0), pertumbuhan bakteri Acetobacter xylinum membentuk metabolit ekstraselular membran nata. Ketebalan nata yang dihasilkan tergantung komposisi limbah kecap dan gula. Hal ini membuktikan bahwa kandungan nitrogen yang terdapat pada limbah kecap cukup untuk pertumbuhan bakteri hingga membentuk nata. Penambahan $\left(\mathrm{NH}_{4}\right)_{2} \mathrm{PO}_{4}$ sebagai sumber nitrogen juga rnempengaruhi ketebalan nata yang dihasilkan.

Pada media yang mengandung nitrogen cukup akan menghasilkan rendemen nata yang banyak, karena nitrogen merangsang pertumbuhan bakteri A. xylinum dengan meningkatkan aktifitas dari bakteri A. xylinum yang selanjutnya akan meningkatkan sintesis polisakarida.

Peningkatan aktifitas bakteri dipengaruhi pula oleh ketersediaan unsurunsur dan ion-ion mineral tertentu (Deavin (1971) dalam Hubeis dkk. (1996)).

Menurut Lapuz (1967) dan Rosario (1982) dalam Hubeis dkk. (1996) untuk merangsang pertumbuhan serta aktifitas bakteri Acetobacter xylinum diperlukan danya sumber Nitrogen yang memadai baik yang berasal dari bahan organik maupun dari anorganik. Kebutuhan minimum nitrogen dalam media kira-kira 1 g/L (Jawetz,1984). Menurut Widia (1984) dan Mashudi (1993) dalam Hubeis (1996), Nitrogen dapat meningkatkan jumlah serat. Hubeis (1996) menambahkan, dengan semakin tebalnya nata ikatan selulosa yang menyusun semakin longgar. Menurut Husein (1996) dalam kecap terdapat berbagai asam amino dan gula yang merupakan bahan nutrisi yang baik untuk pertumbuhan bakteri. Limbah kecap kedelai masih mengandung beberapa bahan organik antara lain, protein $10,32 \%$, lemak 6,93\%, air 52,98\% dan abu 6,72\%. Kecenderungan bertambah tebalnya nata dapat dipengaruhi oleh penambahan sumber nitrogen anorganik $\left.\left(\mathrm{NH}_{4}\right)_{2} \mathrm{PO}_{4}\right)$, serta dipengaruhi oleh penambahan konsentrasi gula. Semakin tinggi konsentrasi gula yang ditambahkan, maka akan meningkatkan ketebalan nata yang dihasilkan (Gambar 1).

Hasil analisis varian penambahan konsentrasi limbah kecap, gula dan $\left(\mathrm{NH}_{4}\right)_{2} \mathrm{PO}_{4}$ terhadap ketebalan nata memiliki nilai signifikan $<0,05$ yang berarti memiliki pengaruh yang nyata secara bebas maupun secara interaksi terhadap ketebalan nata.

Pada Gambar 2 dapat dilihat bahwa penambahan gula dan $\left(\mathrm{NH}_{4}\right)_{2} \mathrm{PO}_{4}$ yang sesuai akan berpengaruh terhadap penambahan ketebalan nata, hal ini dapat disebabkan oleh pemakaian media (limbah kecap, gula dan $\left.\left(\mathrm{NH}_{4}\right)_{2} \mathrm{PO}_{4}\right)$ yang efisien oleh baktcri Acetobacter xylinum sehingga menambah ketebalan nata.

Pada Gambar 3 dapat dilihat bahwa penambahan limbah kecap dan $\left.\left(\mathrm{NH}_{4}\right)_{2} \mathrm{PO}_{4}\right)$ akan berpengaruh terhadap penurunan ketebalan nata, hal ini dapat disebabkan oleh pemakian media yang mengandung banyak sumber $\mathrm{N}$ (limbah kcap, dan $\left(\mathrm{NH}_{4}\right)_{2} \mathrm{PO}_{4}$ ) memicu pertumbuhan bakteri Acetobacter xylinum yang pesat sehingga populasinya meningkat. Seiring dengan meningkatnya populasi bakteri Acetobacter xylinum maka sisa-sisa metabolisme juga turut meningkat (Dwidjoseputro, 1989) yang menjadikan kondisi tidak optimal bagi pertumbuhan Acetobacter xylinum. Hal demikian menyebabkan kemampuan dari bakteri Acetobacter xylinum untuk bermetabolisme pun menjadi berkurang, sehingga selulosa yang dihasilkan menjadi lebih sedikit. 


\section{Derajat Putih}

Salah satu parameter kualitas nata adalah nilai derajat putih. Semakin besar nilai derajat putih, maka kualitas nata semakin baik. Menurut Widia (1994) dan Masyudi (1993) dalam Hubeis dkk. (1996) nata yang baik memiliki derajat putih sekitar 47,75. Penambahan konsentrasi limbah kecap, gula dan $\left(\mathrm{NH}_{4}\right)_{2} \mathrm{PO}_{4}$ berpengaruh terhadap naiknya nilai derajat putih yang dapat dilihat pada Gambar 4.

Semakin tinggi konsentrasi penambahan limbah kecap, gula dan $\left(\mathrm{NH}_{4}\right)_{2} \mathrm{PO}_{4}$ maka nilai derajat putih akan semakin tinggi.

Peningkatan ketebalan akan mempengaruhi naiknya nilai derajat putih. Menurut Hubeis dkk. (1996) ketebalan nata akan mempengaruhi nilai derajat putih bila ikatan antar sel yang terbentuk longgar. Dengan struktur sel yang longgar akan memudahkan terjadinya interaksi antara media fermentasi yang berwarna kecoklatan yang terserap diantara sel-sel nata. Pada saat proses perendaman, media fermentasi yang terserap diantara sel-sel nata disubtisusikan oleh air.

Pada perlakuan (L 2,5 - G 3 N0,5), (L 2,5 - G 6 - N0,5), (L 2,5 - G 9 N0,5) dan (L 2,5 - G 12 - N0,5), kenaikan ketebalan tidak berbanding lurus dengan kenaikan nilai derajat putih. Hal ini dimungkinkan kombinasi perlakuan ini tidak optimal untuk pertumbuhan bakteri Acetobacter xylinum dalam membentuk membran nata.

Hasil analisis varian menunjukan bahwa faktor limbah kecap, gula, interaksi limbah kecap dan gula serta interaksi limbah kecap dan $\left(\mathrm{NH}_{4}\right)_{2} \mathrm{PO}_{4}$ memiliki nilai signifikan $<0,05$ yang berarti memiliki pengaruh yang nyata secara bebas maupun secara interaksi terhadap derajat putih nata. Sedangkan faktor $\left(\mathrm{NH}_{4}\right)_{2} \mathrm{PO}_{4}$, interaksi gula dan $\left(\mathrm{NH}_{4}\right)_{2} \mathrm{PO}_{4}$ serta interaksi limbah kecap, gula dan $\left(\mathrm{NH}_{4}\right)_{2} \mathrm{PO}_{4}$ memiliki nilai signifikan > 0,05 yang berarti tidak memiliki pengaruh yang nyata secara bebas maupun secara interaksi terhadap derajat putih.
pH

$\mathrm{pH}$ sebelum dan sesudah fermentasi cenderung tidak ada perubahan yang nyata. Tidak adanya perubahan yang signifikan disebabkan asam yang terbentuk adalah asam asetat yang merupakan asam lemah dalam jumlah yang sedikit sehingga tidak terlalu berpengaruh terhadap perubahan $\mathrm{pH}$.

\section{Uji Organoleptik}

Uji organoleptik dilakukan dengan membandingkan nata de soya yang dihasilkan dengan produk nata de coco. Pada uji ini ternyata nata de soya yang dihasilkan cukup diterima oleh para panelis sebanyak 10 orang, dapat dilihat pada Tabel 2. Secara keseluruhan produk A (nata de soya) dan produk B (nata de coco) tidak ada perbedaan. Meskipun secara rangking Produk B lebih unggul.

\section{Uji Proksimat}

Hasil analisa proksimat yang dilakukan terhadap produk nata de soya yang dihasilkan dengan parameter kadar air, kadar abu, serat kasar, protein, lemak serta karbohidrat dapat dilihat pada Tabel 3, Pada para meter serat kasar dengan hasil 2,75\% sudah memenuhi sarat SNI tentang nata dalam kemasan yaitu serat kasar nata maksimal 4,5\%. Lebih dari $90 \%$ kandungan nata adalah air. Hal inl disebabkan ada rongga pada membran selulosa nata. Pada parameter serat kasar terlihat perbedaan yang nyata antara nata de soya yang dihasilkan dengan nata de coco. 
Tabel 1. Kombinasi Antara Limbah Kecap, Gula dan $\left(\mathrm{NH}_{4}\right)_{2} \mathrm{PO}_{4}$ pada Pembuatan Media Fermentasi Nata de soya

\begin{tabular}{|c|c|c|c|c|c|c|}
\hline \multirow{2}{*}{$\begin{array}{l}\text { Kombinasi gula dan } \\
\left(\mathrm{NH}_{4}\right)_{2} \mathrm{PO}_{4}\end{array}$} & \multicolumn{6}{|c|}{ Konsentrasi Limbah Kecap } \\
\hline & $\overline{\mathrm{L} 0}$ & $\mathrm{~L} 2,5$ & L 5 & $\mathrm{~L} 7,5$ & L 10 & $\mathrm{~L} 12,5$ \\
\hline & GO & GO & GO & GO & GO & GO \\
\hline G 0 & NO & NO & NO & NO & NO & NO \\
\hline \multirow[t]{2}{*}{ N 0} & LO & $\mathrm{L} 2,5$ & L5 & $\mathrm{L} 7,5$ & L10 & $\mathrm{L} 12,5$ \\
\hline & G3 & G3 & G3 & G3 & G3 & G3 \\
\hline G 3 & NO & NO & NO & NO & NO & NO \\
\hline \multirow[t]{2}{*}{ N 0} & LO & $\mathrm{L} 2,5$ & L5 & $\mathrm{L} 7,5$ & L10 & L 12,5 \\
\hline & G6 & G6 & G6 & G6 & G6 & G6 \\
\hline G 6 & NO & NO & NO & NO & NO & NO \\
\hline \multirow[t]{2}{*}{ N 0} & LO & $\mathrm{L} 2,5$ & L5 & $\mathrm{L} 7,5$ & L10 & $\mathrm{L} 12,5$ \\
\hline & G9 & G9 & G9 & G9 & G9 & G9 \\
\hline G 9 & NO & NO & NO & NO & NO & NO \\
\hline \multirow[t]{2}{*}{ N 0} & LO & L2,5 & L5 & L7,5 & L10 & L 12,5 \\
\hline & $\mathrm{G} 12$ & G12 & G12 & G12 & G12 & G12 \\
\hline G 12 & $\mathrm{NO}$ & NO & NO & NO & NO & NO \\
\hline \multirow[t]{2}{*}{ N 0} & LO & L2,5 & L5 & L7,5 & $\mathrm{HO}$ & L12.5 \\
\hline & GO & GO & GO & GO & GO & GO \\
\hline G0 & N0,5 & N0,5 & N0,5 & N0,5 & N0,5 & N0,5 \\
\hline \multirow[t]{2}{*}{ N 0,5} & LO & L2,5 & L5 & L7,5 & L10 & L12,5 \\
\hline & G3 & G3 & G3 & G3 & G3 & G3 \\
\hline G 3 & N0,5 & N0,5 & N0,5 & N0,5 & N0,5 & N0,5 \\
\hline \multirow[t]{2}{*}{ N 0,5} & LO & L2,5 & L5 & L7,5 & L10 & $\mathrm{L} 12,5$ \\
\hline & G6 & G6 & G6 & G6 & G6 & G6 \\
\hline G 6 & N0,5 & $\mathrm{N} 0,5$ & N0,5 & N0,5 & N0,5 & N0,5 \\
\hline \multirow[t]{2}{*}{ N 0,5} & LO & L2,5 & L5 & L7,5 & L10 & L12,5 \\
\hline & G9 & G9 & G9 & G9 & G9 & G9 \\
\hline G9 & $\mathrm{N} 0,5$ & N0,5 & N0,5 & N0,5 & N0,5 & N0,5 \\
\hline \multirow[t]{2}{*}{$\begin{array}{l}\text { N0.5 } \\
\text { N } 0,5\end{array}$} & LO & L2,5 & L5 & L7,5 & L 10 & L12,5 \\
\hline & G12 & G12 & G12 & G12 & G12 & G12 \\
\hline G12 & $\mathrm{N} 0,5$ & N0,5 & N0,5 & N0,5 & N0,5 & N0,5 \\
\hline LO & $\mathrm{L} 2,5$ & L5 & $\mathrm{L} 7,5$ & L 10 & L12,5 & L12,5 \\
\hline
\end{tabular}




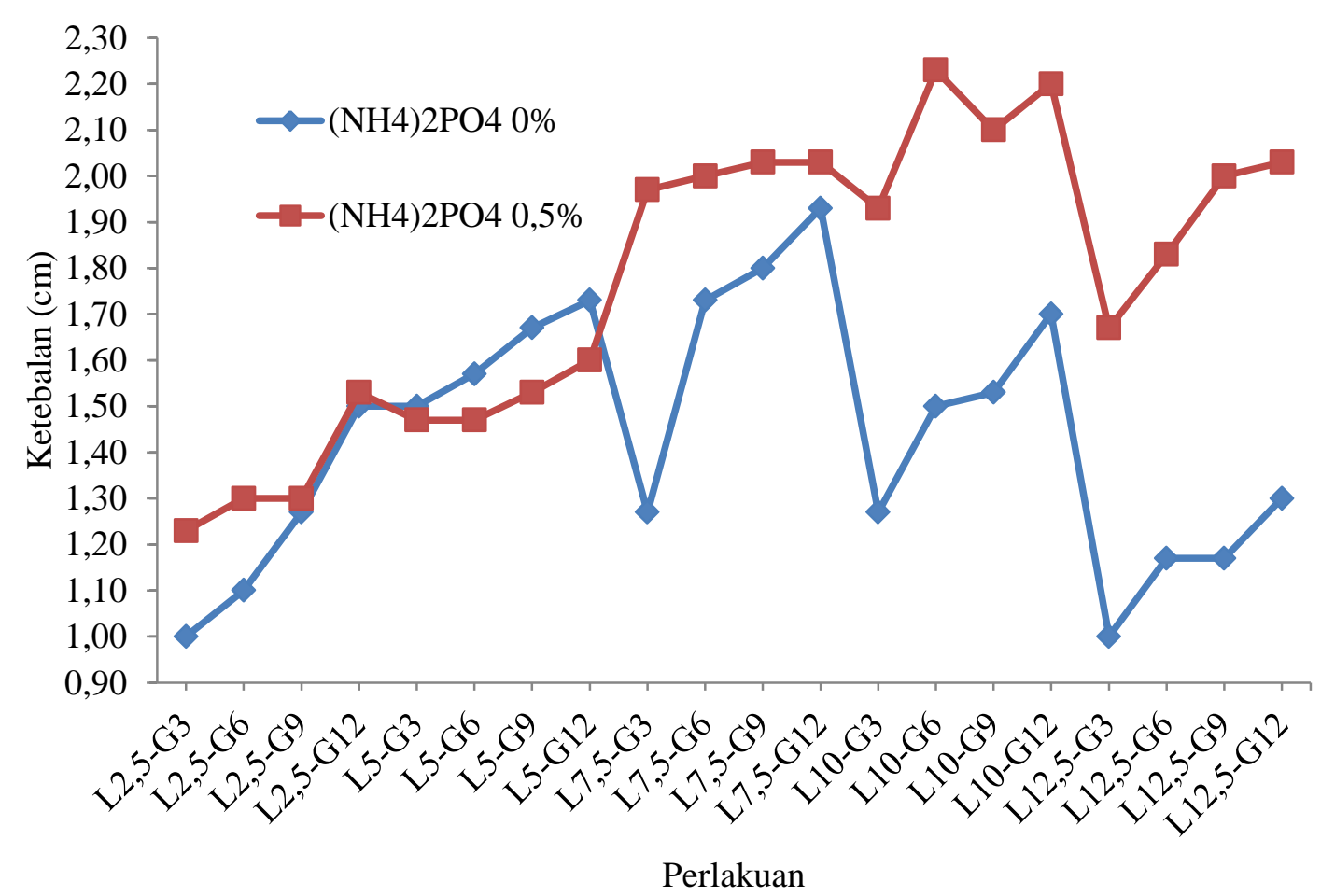

Gambar 1. Ketebalan Nata Pada Perlakuan Penambahan $\left(\mathrm{NH}_{4}\right)_{2} \mathrm{PO}_{4} 0 \%$ dan Penambahan $\left(\mathrm{NH}_{4}\right)_{2} \mathrm{PO}_{4} 0,5 \%$

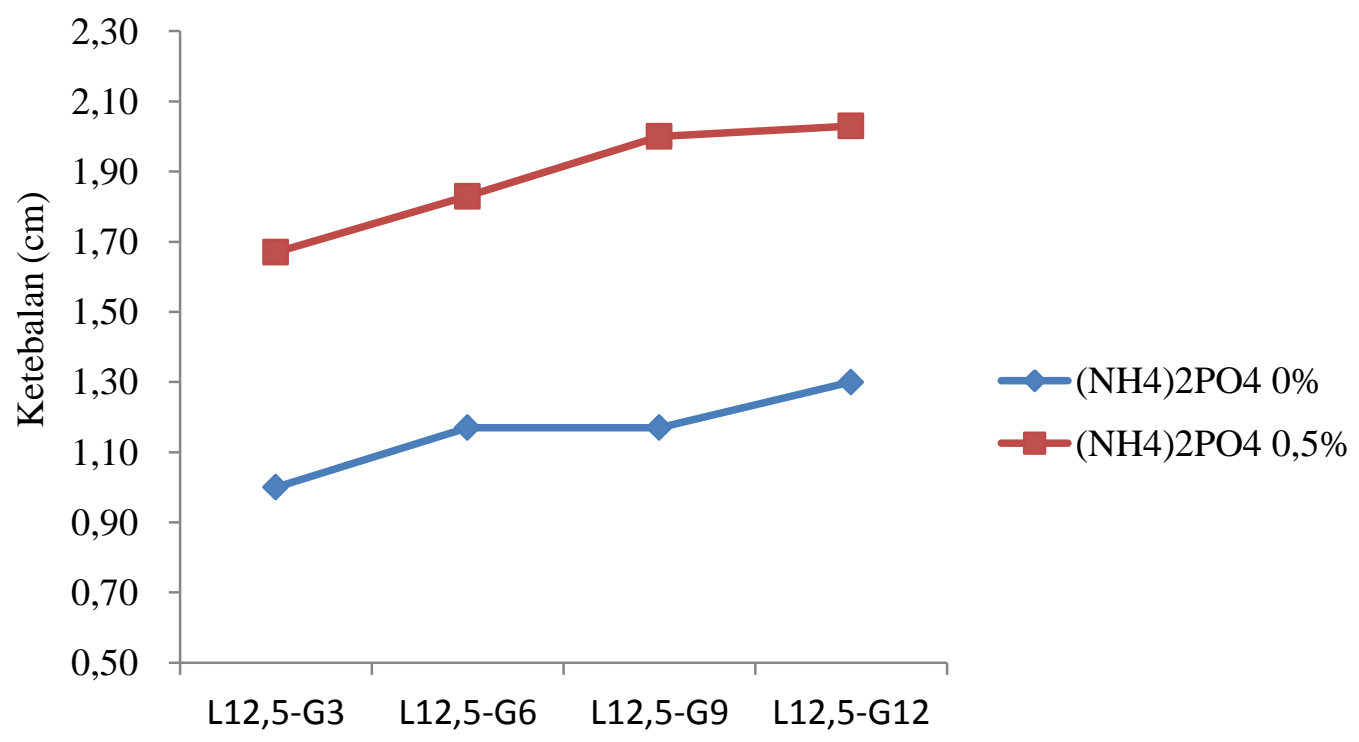

Perlakuan

Gambar 2. Grafik Ketebalan Nata Pada Kombinasi Perlakuan Penambahan Gula dan $\left(\mathrm{NH}_{4}\right)_{2} \mathrm{PO}_{4}$ Sedangkan Penambahan Limbah Kecap Tetap (L12,5) 


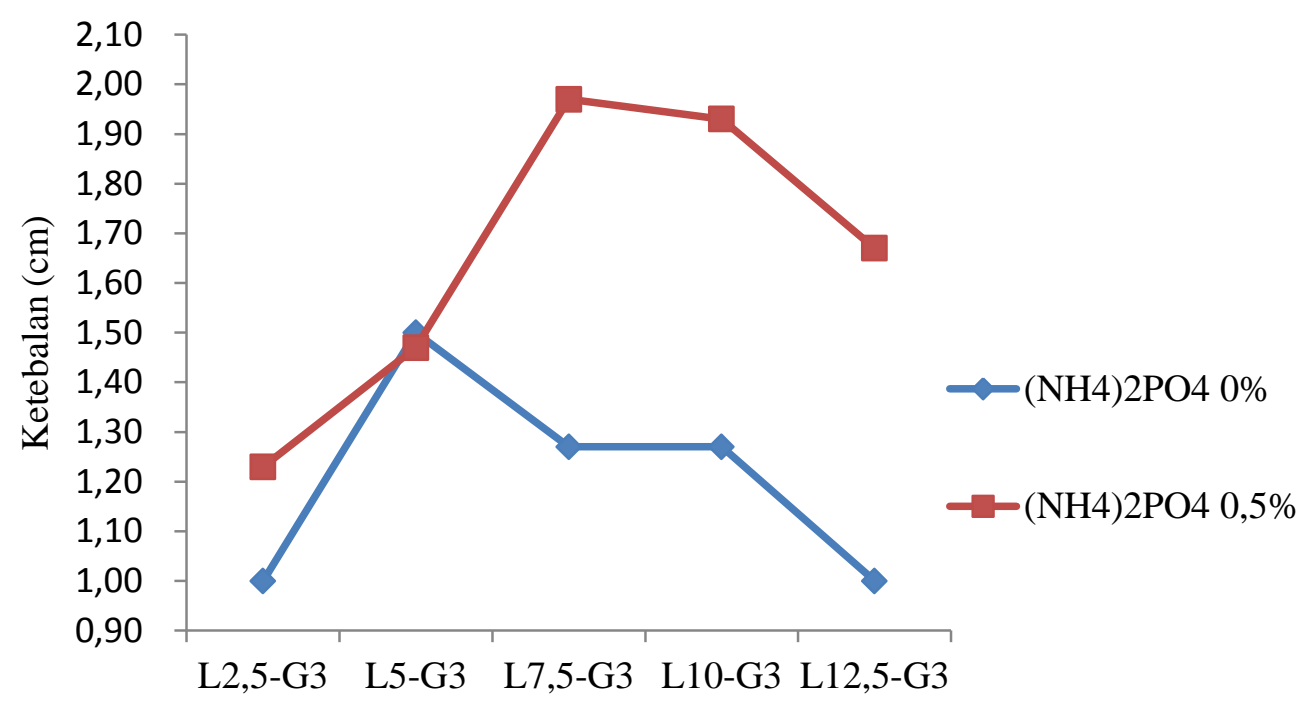

Perlakuan

Gambar 3. Ketebalan Nata Pada Kombinasi Perlakuan Penambahan Limbah Kecap dan $\left(\mathrm{NH}_{4}\right)_{2} \mathrm{PO}_{4}$ Sedangkan Penambahan Gula Tetap (G3)

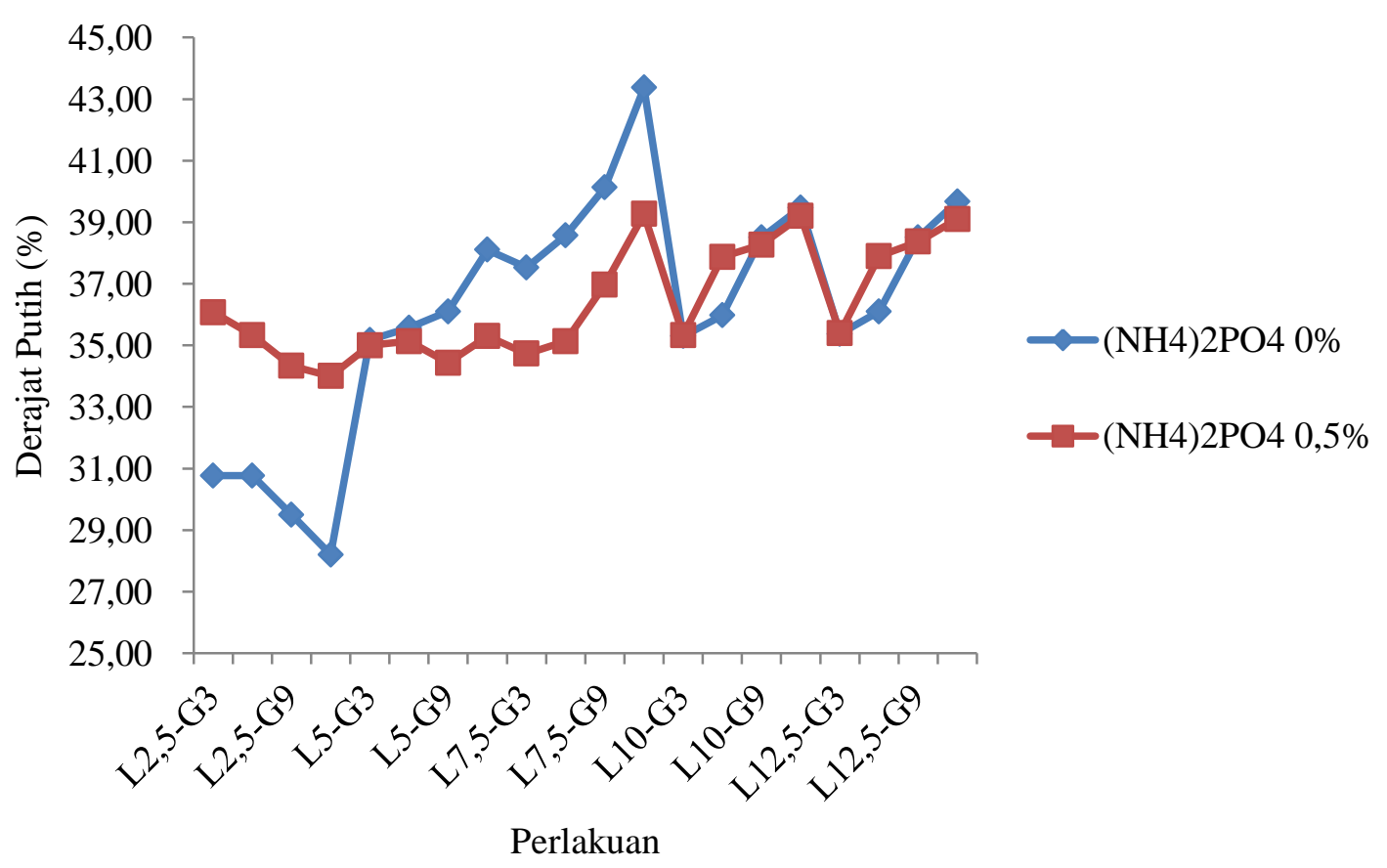

Gambar 4. Derajat Putih Nata Pada Perlakuan Penambahan $\left(\mathrm{NH}_{4}\right)_{2} \mathrm{PO}_{4} 0 \%$ dan Peanambahan $\left(\mathrm{NH}_{4}\right)_{2} \mathrm{PO}_{4} 0,5 \%$ 
Tabel 2. Hasil Kuisioner Panelis Perbandingan nata de soya yang dihasilkan dengan produk nata de coco yang ada dipasaran

\begin{tabular}{lcccc}
\hline $\begin{array}{l}\text { No } \\
\text { Panelis }\end{array}$ & \multicolumn{2}{c}{ Produk A (nata de soya) } & Produk B (nata de coco) & Perbedaan \\
\cline { 2 - 4 } & Tekstur Rasa & $\begin{array}{c}\text { aroma } \\
\text { Rangking } \\
\text { Tekstur }\end{array}$ & Rasa & $\begin{array}{l}\text { aroma } \\
\text { Rangking }\end{array}$ \\
\hline
\end{tabular}

Perlakuan L7,5-G12-N0 dengan ketebalan 1,93 dan derajat putih 43,37

\begin{tabular}{|c|c|c|c|c|c|c|c|c|c|c|}
\hline 1 & 1 & Suka & Biasa & Biasa & 1 & Suka & Suka & Biasa & 2 & $\begin{array}{l}\text { Tidak berbeda } \\
\text { nyata }\end{array}$ \\
\hline 2 & 2 & Biasa & Biasa & Biasa & 2 & Suka & Biasa & Biasa & 1 & $\begin{array}{l}\text { Tidak berbeda } \\
\text { nyata }\end{array}$ \\
\hline 3 & 3 & Suka & Biasa & Biasa & 2 & Suka & Biasa & Suka & 1 & $\begin{array}{l}\text { Tidak berbeda } \\
\text { nyata }\end{array}$ \\
\hline 4 & 4 & Suka & Biasa & Biasa & 2 & Suka & Biasa & Biasa & 1 & $\begin{array}{l}\text { Tidak berbeda } \\
\text { nyata }\end{array}$ \\
\hline 5 & 5 & Suka & Biasa & Biasa & 2 & Suka & Biasa & Biasa & 1 & $\begin{array}{l}\text { Tidak berbeda } \\
\text { nyata }\end{array}$ \\
\hline 6 & 6 & Biasa & Biasa & Biasa & 2 & Suka & Suka & Biasa & 1 & $\begin{array}{l}\text { Tidak berbeda } \\
\text { nyata }\end{array}$ \\
\hline 7 & 7 & Biasa & Biasa & Biasa & 2 & Suka & Biasa & Biasa & 1 & $\begin{array}{l}\text { Tidak berbeda } \\
\text { nyata }\end{array}$ \\
\hline 8 & 8 & Suka & Biasa & Biasa & 2 & Suka & Biasa & Biasa & 1 & $\begin{array}{l}\text { Tidak berbeda } \\
\text { nyata }\end{array}$ \\
\hline 9 & 9 & Suka & Biasa & Biasa & 1 & Bjasa & Biasa & Biasa & 2 & $\begin{array}{l}\text { Tidak berbeda } \\
\text { nyata }\end{array}$ \\
\hline 10 & 10 & Suka & Biasa & Biasa & 2 & Suka & Biasa & Biasa & 1 & $\begin{array}{l}\text { Tidak berbeda } \\
\text { nyata }\end{array}$ \\
\hline \multicolumn{11}{|c|}{ Perlakuan L10-G6-N0,5 dengan ketebalan 2,23 dan derajat putih 37,87 } \\
\hline 1 & 1 & Biasa & Biasa & Biasa & 2 & Suka & Suka & suka & 1 & $\begin{array}{l}\text { Tidak berbeda } \\
\text { nyata }\end{array}$ \\
\hline 2 & 2 & Suka & Biasa & Biasa & 1 & Biasa & Biasa & Biasa & 2 & $\begin{array}{l}\text { Tidak berbeda } \\
\text { nyata }\end{array}$ \\
\hline 3 & 3 & Biasa & Biasa & Biasa & 2 & Suka & Biasa & Biasa & 1 & $\begin{array}{l}\text { Tidak berbeda } \\
\text { nyata }\end{array}$ \\
\hline 4 & 4 & Biasa & Biasa & Biasa & 2 & Suka & Biasa & Biasa & 1 & $\begin{array}{l}\text { Tidak berbeda } \\
\text { nyata }\end{array}$ \\
\hline 5 & 5 & Biasa & Biasa & Biasa & 2 & Suka & Biasa & Biasa & 1 & $\begin{array}{l}\text { Tidak berbeda } \\
\text { nyata }\end{array}$ \\
\hline 6 & 6 & Suka & Biasa & Biasa & 2 & Suka & Suka & Biasa & 1 & $\begin{array}{l}\text { Tidak berbeda } \\
\text { nyata }\end{array}$ \\
\hline 7 & 7 & Biasa & Biasa & Biasa & 2 & Biasa & Biasa & Biasa & 1 & $\begin{array}{l}\text { Tidak berbeda } \\
\text { nyata }\end{array}$ \\
\hline 8 & 8 & Biasa & Biasa & Biasa & 1 & Biasa & Biasa & Biasa & 2 & $\begin{array}{l}\text { Tidak berbeda } \\
\text { nyata }\end{array}$ \\
\hline 9 & 9 & Biasa & Biasa & Biasa & 2 & Biasa & Suka & Biasa & 1 & $\begin{array}{l}\text { Tidak berbeda } \\
\text { nyata }\end{array}$ \\
\hline 10 & 10 & Suka & Biasa & Biasa & 2 & Suka & Biasa & Biasa & 1 & $\begin{array}{l}\text { Tidak berbeda } \\
\text { nyata }\end{array}$ \\
\hline
\end{tabular}


Tabel 3. Perbandingan Hasil Uji Proksimat Antara Nata De Soya Dengan Nata De Coco

\begin{tabular}{clcc}
\hline No. & \multicolumn{2}{c}{ Parameter } & Hasil (\%) \\
\cline { 3 - 4 } & & Nata de soya & Nata de coco \\
\hline 1. & Kadar air & 94 & 95 \\
2. & Kadar abu & 0,31 & 0,20 \\
3. & Serat kasar & 2,75 & 3,30 \\
4. & Protein & 2,60 & 2,40 \\
5. & Lemak & 0,35 & 0,35 \\
6. & Karbohidrat & 0,90 & 1,00 \\
\hline
\end{tabular}

\section{KESIMPULAN}

Perlakuan konsentrasi limbah kecap, gula dan $\left(\mathrm{NH}_{4}\right)_{2} \mathrm{PO}_{4}$ berpengaruh nyata terhadap ketabalan nata yang dihasilkan, baik secara bebas dan secara interaksi.

Komposisi yang paling baik adalah media dengan limbah kecap $10 \%$, gula $6 \%$ dan $\left(\mathrm{NH}_{4}\right)_{2} \mathrm{PO}_{4} 0.5 \%$ dengan ketebalan 2,23 cm dan derajat putih $37,87 \%$.

\section{DAFTAR PUSTAKA}

Darmajana Doddy A,, 2004, Pengaruh Ketinggian Media Dan Waktu Inkubasi Terhadap Beberapa Karakteristik Fisik Nata De Soya, Presiding Seminar Nasional Rekayasa Kimia Dan Proses, ISSN : 1411 - 4216, 2004, Bste Pengembangan Teknologi Tepat Guna - LIPI J1. K.S. Tubun 5 Subang 41211

Dwidjoseputro, D., 1989. Dasar - Dasar Mikrobiologi. Malang: Djambatan.

Hubeis, M., 1996. Formulasi Nata de pina, Buletin Teknologi \& Indrusiri Pangan, ISSN 216-2318 Vol. VII No. 2, Institut Pertanian Bogor.
Husein, H. 1996. Mempelajari pengaruh lama Proses Moromi Terhadap Pembentukan Prekursor Flavor Dan Flafor Kecap Manis. Penelitian Pasca sarjan IPB, Bogor.

Jawetz, E., 1984. Mikrobiologi untuk Profesi Kesehatan. Edisi 16, EGG, Jakarta.

Purwoko T., Handajani N.S., 2007 , Kandungan Protein Kecap Manis Tanpa Fermentasi Moromi Hasil Fermentasi Rhizopus oiyzae dan $R$. oligosporus, Biodiversitas, ISSN : 1412-033X, Vol. 8 No. 2, Bogor, Halaman: 223-227

Rahayu, S. E. 1985. Teknik Pembuatan Kecap Dengan Aspergillus oryzae Dan Aspergillus sojae. Laporan penelitian, Fakultas teknologi Pertanian,UGM, Dep. P\&K, Yogyakarta.

Wowor Liana Y., Muis M., Arinong Abd. R., 2007, Analisis Usaha Pembuatan Nata De Coco Dengan Menggunakan Sumber Dan Kandungan N Yang Berbeda, Jurnal Agrisistem, ISSN 18584330, Vol. 3 No. 2. 